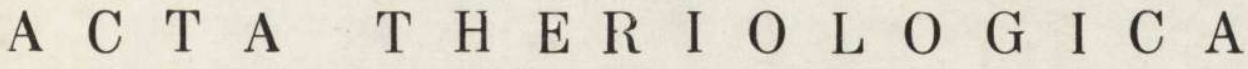 \\ VOL. XII, 21: $335-338$ \\ BIAEOWIEŻA \\ 30.XII.1967
}

Kazimierz K O W A L S K I

\section{The Evolution and Fossil Remains of the European Bison}

\author{
Bisoniana XVII
}

\begin{abstract}
The author discusses the evolution of species of the genus Bison $\mathrm{H}$. Smith, dealing in greater detail with the origin of Bison bonasus (L.). The fossil remains of this species indicate that it was connected with the deciduous forest zone and did not appear in Central Europe until the late Holocene.
\end{abstract}

The genus Bison H. S m ith appeared in the Pliocene of south and east Asia, where three species are known from this period: $B$. sivalensis ( $\mathrm{F} \mathrm{a} \mathrm{lc} \mathrm{on} \mathrm{er),} \mathrm{B.} \mathrm{palaeosinensis} \mathrm{(} \mathrm{T}$ e ilh a r d de $\mathrm{Ch}$ ardin et $\mathrm{P}$ ive$\mathrm{te} \mathrm{a} \mathrm{u}$ ) and $B$. hanaizumiensis $\mathrm{M}$ a tsumoto et $\mathrm{M}$ ori. These forms have all the characters of the genus Bison, but are distinguished by the smallness of their body dimensions in comparison with the later representatives of this genus.

In the Early Pleistocene the genus Bison spread over Asia and reached Europe. In the Middle Pleistocene (and probably once again during the Late Pleistocene) it penetrated over the land connection at the Bering Strait to America, where its range extended as far as Florida and $\mathrm{Me}$ xico. It never spread as far as South America or Africa.

Monographs of the genus Bison are based so for only on part of the existing materials. Hilzheimer $(1910 ; 1918)$ examined material from West Europe, Grom ova (1935) from the Soviet Union and Skinner \& K a is en (1947) from North America. No defined evolutionary tendencies have been found within the genus. Teeth do not exhibit specific differences. Body dimensions vary, particularly the dimensions and shape of the horns. There would appear to be little justification for the distinction made by $\mathrm{Sk}$ in $\mathrm{n} \in \mathrm{r} \& \mathrm{~K}$ a is e $\mathrm{n}$ (l.c.) of numerous subgenera and species within the genus Bison in view of the established fact that the present-day forms readily crossbreed and that these systematic units differ only as to the shape and dimensions of the horns.

In Europe the genus Bison appeared in the Oldest Pleistocene (Villafranchien) first in the east, then also in the west of the continent. This 
is a small form named B. schoetensacki Fre uden berg. During the glacial period Mindel European bisons became larger and their horns more massive. During the Riss and Würm glaciations in Europe (together with England) and also in Asia as far as Manchuria the very large species of bison with powerful horns, known as B. priscus (B oja n u s) occurred. It is one of the components of the Pleistocene steppetundra fauna and accompanies such species as the mammoth, wooly rhinoceros, horse and cave bear. Towards the end of the Pleistocene this species appears to have become dwarfed and in Denmark, according to Degerbol \& I versen (1945), a form is present similar to the present-day European bison, called by the two authors $B$. bonasus arbustotundrorum. The $B$. priscus line finally died out during the Dryas period towards the end of the Pleistocene.

There are two hypotheses as to the origin of the contemporary European bison, Bison bonasus (L inna e u s). H il zh eimer (1918) and after him the majority of zoologists in Western Europe, assume that there were two independent lines of development over the whole of the Pleistocene. One of them, including the small forest forms, leads from $B$. schoetensacki straight to $B$. bonasus. The great-horned $B$. priscus, inhabitant of steppe-tundra formed during the older glacial periods, developed independently and died without leaving progeny at the end of the final glacial period.

In G r o m ova's opinion (1965) there is only one line of development among bison in the Pleistocene of Europe, leading from $B$. schoetensacki through $B$. priscus to the extant $B$. bonasus. In cold periods such bisons were larger, and during warmer periods - smaller.

The fact that $B$. bonasus is connected with deciduous forests and does not appear in Central Europe until the Late Holocene, several thousand years after the extinction of the steppe-tundra form, B. priscus, indicates that the present-day bison was formed at any rate earlier than in the postglacial period, possibly during the final glaciation in one of the forest regions in Southern Europe.

In view of the absence of $B$. bonasus in the Iberian Peninsula and to the south of the Appenine Peninsula it is most probable that this took place in the Caucasus Mountains region. The bison did not expand its range to the north and west from this region until the late post-glacial period.

Remains of Bison priscus from the, final glaciation period, or not exactly dated, have been found in Poland. Complete skuls of this species have been described by $\mathrm{Niezabitowski}(1948)$ and $\mathrm{Krysiak}$ (1952). Remains of $B$. bonasus are few in number and in general not dated (N iezabitowski, 1931; 1938); they have been found in Pomerania, in the Wielkopolska district, in the Rzeszów and Podhale regions. B o chenek (1955) described remains of the bison from the 13 th century castle at Szaflary in the Podhale region. The list given by $\mathrm{Pa}$ a ver (1965) shows that the bison did not appear in Lithuania or Latvia, that is, to the north of Poland, until the beginning of the present era, and that it is more numerous in the second millenium of our era. The European bison never penetrated as far as Esthonia, beyond the 
limit of deciduous forests.

There is an urgent need to obtain a knowledge of the remains of $B i$ son bonasus from Europe, especially those which can be dated by the radioactive carbon method, pollen analysis or by their connection with traces of human culture. This will make it possible to obtain a picture of the process of the postglacial expansion of this species, and then of its disappearance as the result of human activities. For the purposes of the paleontology of the genus Bison it would be useful to obtain a knowledge on recent material of allometry in the skull of the contemporary bison, which would then facilitate evaluation of the value of characters considered of systematic importance.

\section{REFERENCES}

1. Bochen ek S., 1955: Szczątki żubra, Bison bonasus (L.), z Podhala. Acta theriol., 1, 2: 15-25. Warszawa.

2. Degerbol M. \& Iversen J., 1945: The Bison in Denmark. Danmarks geol. undesogelse, 2, 73: $1-62$.

3. Hilzheimer M., 1910: Beitrag zur Kenntnis der fossilen Bisonten. Sitzber. Ges. naturf. Fr., 4: 136-146. Berlin.

4. Hilzheimer M., 1918: Dritter Beitrag zur Kenntnis der Bisonten. Arch. Naturg., 84, A, 6: 41-87. Leipzig.

5. Gromova V., 1935: Piervobytnyj zubr (Bison priscus Bojanus) v SSSR. Trudy zool. Inst. Akad. Nauk, 2: 77-204. Leningrad.

6. Gromova V., 1965: Kratkij obzor četvertičnyh mlekopitajuščih Evropy. Nauka, 1-142. Moskva.

7. Krysiak K., 1952: Znalezisko dwóch czaszek prażubra - Bison priscus B ojan. z ziem polskich. Wiadomości archeol., 18, 3-4: 185-199. Warszawa.

8. Niezabitowski E. L., 1931: Szczątki kopalne żubra (Bison bonasus L.) na ziemiach Polski. Roczniki Nauk rol., 26: 7-50. Poznań.

9. Nieza bitowski E. L.. 1938: Szczątki kopalne żubra z Wielkopolski. Kosmos, A 63: 439-444. Lwów.

10. Niezabitowski E. L., 1948: Czaszka żubra długorogiego Bos priscus B ojanus z Gryżyny. Fragm. faun. Mus. zool. pol., 5, 18: 305-308. Warszawa.

11. P a a ver K., 1965: Formirowanie teriofauny i izmenčivost' mlekopitajuščih Pribaltiki $v$ golocenie. Akad. Nauk Est. SSR, Inst. Zool. i Bot.: 1-492. Tartu.

12. Skinner M. P. \& K a is en O. C., 1947: The fossil bison of Alaska and preliminary revision of the genus. Bull. Amer. Mus. nat. Hist., 89, 3: 125-256. New York.

Received, February 1, 1967 .

Polish Academy of Sciences,

Institute of Systematic Zoology,

Kraków, Sławkowska 17. 
Kazimierz KOWALSKI

\section{EWOLUCJA I SZCZĄTKI KOPALNE ŻUBRA}

\section{Streszczenie}

Omówiono ewolucje gatunków rodzaju Bison H. Smith, zajmując sie szerzej pochodzeniem Bison bonasus (L.). Szczątki kopalne tego gatunku wskazują, że by? on związany ze strefą lasów liściastych i w Europie środkowej pojawił się dopiero w późnym holocenie. 